\title{
Port Adaptation and Efficiency: An Empirical Study of Ghanaian Ports
}

\author{
Ruhaimatu Abudu ${ }^{1}$, Prof. Shiyuan Zheng ${ }^{2}$ \& Emmanuel Anu Thompson ${ }^{1}$ \\ ${ }^{1}$ College of Transport and Communication, Shanghai Maritime University, Shanghai, China \\ 2 Professor, College of Transport and Communication, Shanghai Maritime University, \\ Shanghai, China \\ Correspondence: Ruhaimatu Abudu, College of Transport and Communication, Shanghai \\ Maritime University, Shanghai, China. E-mail: ruhaimatuabudu@gmail.com
}

Received: August 15, 2021 Accepted: September 3, 2021 Published: September 8, 2021

doi:10.5296/ijrd.v8i2.18942 URL: http://dx.doi.org/10.5296/ijrd.v8i2.18942

\begin{abstract}
The port being an economical leg of countries development and thereby affected by climate change creates a substantial cost to the various stakeholders since is described as a "business" hub. It is, therefore, essential that ports across the globe attribute much importance to climate adaptation and its relation to port efficiency, especially for the coming years. The need to establish the effect these variables have on each other has become paramount. For this study, an empirical analysis of Ghanaian ports is being reviewed for the past and future annual efficiencies and adaptation scores. The annual efficiencies of both ports are calculated using various variables as inputs and outputs with the DEA Frontier software to calculate the DEA-CCR of the study ports. To assess the adaptation scores of each port, questionnaires and interviews were conducted based on four (4) major factors that affect port adaptation. This research also employs the linear mixed model and one-way ANOVA to assess the means of the data groups obtained for 2009-2020 \& 2021-2040 respectively. This research aimed to analyse the significant relationship between port adaptation and efficiency for past and future years while highlighting the adaptative strategies of Ghanaian ports. The concluding chapters of this research represent the data analysis, policy recommendation for the stakeholders of Ghanaian ports, and also recommendations that are deemed useful for further research.
\end{abstract}

Keywords: Climate Change; Adaptation; Efficiency; DEA; GPHA; Linear Mixed Model \& ANOVA

\section{Introduction}

The growing concerns for disasters caused in the maritime industry and its contribution to 
climate change have led to the implementation of various conventions and regulations by regulatory bodies in the maritime industry such as the International Maritime Organization (IMO). Events including the Exxon Valdez, Herald of Free Enterprise, and the Titanic led to the implementation of some regulations such as MARPOL (International Convention for the Prevention of Pollution from Ships) and SOLAS (International Convention for the Safety of Life at Sea) (WMU, 2017). This has also led to many researchers concentrating on the greening approach in the maritime industry (Davarzani et al, 2015).

Seaport being the interface between sea and land (Stopford, 2009) and an essential leg of the maritime supply chain, is also faced with the consequences of climate change. More than $80 \%$ of the world's trade in weight is being handled at the port (Notteboom \& Rodrigue, 2007), and impact of the climate change goes a long way to affect the world economy. (Becker et al., 2012) asserted to the fact that port authorities believe that climate change will have a direct impact on the operations of seaports. Sea level rise, groundwater, temperature, precipitation, wave, wind, salinity, and humidity were identified as the significant climate variables at the port, with waves having the highest risk score (Mutombo \& Ölçer, 2017).

Despite the numerous researches on climate change, only a few focusing on the maritime and transportation industry with little on port adaptive measures. For instance, (Song \& Parola, 2015) focused on port management and the creation of a global supply chain with (Fahimnia, et al, 2015) researching on the trade-off components in terms of cost and environmental degradation. ( $\mathrm{Ng}$ et al., 2013) pointed out some adaptation strategies for selected Australian Ports; the paper further examined the types of adaptation strategies as being the hard and soft strategies with the hard aspects mostly in practice. (Randrianarisoa \& Zhang, 2019) also echoed on the investment adaptation to climate change. Seaports operate along coastal regions and being the backbone of global development requires strategic planning, investment, and operation for its development and reduction of the impact of climate change (Becker et al., 2013). The assessment of ports should be supported with Climate impact, adaptation, and vulnerability (CIAV) decision-making by decision-makers of the port (Duncan McIntosh \& Becker, 2017).

Ghana was ranked among the first 10 countries in the world affected by climate change; this indicates the role climate change effect plays in the country with over 100 deaths rates (Global climate risk index, 2017). A rise in temperatures, tropical storms, delay in rainfall, longer drought, and related weather diseases are the major consequences of climate change in Ghana with little adaptative measures; rendering the country vulnerable and huge investments for infrastructure reconstructions.

The various seaports in Ghana including the inland water ports are the major revenue generators for the country's development. Periodic drops in water level due to temperature rise and misty conditions affecting visibility have been identified as the major effects of climate change on the various ports in Ghana. The ports depending on their hinterlands for cargoes face some challenges since most of the hinterlands are affected by extreme weather problems such as excessive rainfall or a rise in high temperatures affecting their supply chain. 


\section{Port Adaptation and Efficiency}

\subsection{Port Adaptation and Strategies}

Adaptation refers to the ability of a system to cope with exogenous factors; the underlying factor for adaptation is an adjustment (Brooks, 2003). In other words, port adaptation is the ability of a port system (infrastructure, superstructure, and administrative system) to adjust to changes in the environment or external factors that can affect port operations. In the face of adaptation, vulnerability and risks place a major important role in "natural" occurrences. Few methodologies on port adaptation outlined the various adaptation strategies implemented by some port authorities. ( $\mathrm{Ng}$ et al., 2013) outlined that port managers have given much attention to climate change as a global issue with adaptation strategies being isolated; with effective adaptation not focusing on the physical layout and engineering work but the ability of port administration to transform the current operating and planning practices of the ports. ( $\mathrm{Ng}$ et al., 2013) classified adaptation strategies into hard and soft strategies; with the hard strategies including the investment in port facilities such as breakwaters, quay walls, or even the berthing facilities (Gouldby \& Hunter, 2021). Soft strategies however deal with the managerial or the implementation of climate change adaptation policies in the port's administrative system.

Adaptation strategy policies for the maritime industry may differ; depending on the leg of the chain, nature of the natural occurrence, and the geographical location of the port. Sea level rise common to San Diego Port in the United States (Messner et al., 2016), typhoon waves experienced by Taiwanese ports (Yang \& Ge, 2020), extreme rainfall and wind, tropical storms were identified as the primary risk of climate change to Australian Ports (Ng et al., 2013); drop in water level at the Port of Montreal, Canada (Slack \& Comtois, 2016); these different climate change impact will require different adaptation approach. Adaptation strategies aim at minimizing the impact of extreme weather conditions and its management programs may include; have a long-term impact, having monitoring strategies in place, evaluating the results of the strategies, assessing the progress of the strategies, and re-evaluation of policies and actions (Yang \& Ge, 2020). Due to the huge capital investment for ports, adaptation strategies should be given much attention by the various stakeholders of the port.

\subsection{Port Efficiency}

The study on port efficiency started in the mid-90s with significant progress over the years. Port efficiency in the maritime sector was appreciated through the works of (Charnes et al., 1978; Cullinane et al., 2005; Cullinane \& Wang, 2010; Estache et al., 2002.; González \& Trujillo, 2007). Efficiency in literal terms meaning to be "productive" with the use of resources available. Likewise, in every other sector striving to be effective, the stakeholders of the port industry require the same. Different sectors use KPIs to measure their efficiency; likewise, the port sector has employed models such as the Data Envelopment Analysis (DEA), Stochastic Frontier Analysis (SFA), Regression Analysis, and even the Full Disposal Hull Model (FDH) to measure their efficiency as well. These models aim to assess the efficiency 
of ports but the variables used are different with varying advantages and disadvantages. (Aigner et al., 1977; Førsund et al., 1980; Schmidt \& Sickles, 2015) employed the Stochastic Frontier Analysis model to establish the relationship with efficiency. Data Envelopment Analysis having gained a populace among researchers such as (Cooper \& Seiford, 2007; van Dyck, 2015; Itoh, 2002; Roll \& Hayuth, 1993) have also been used to that effect.

The concept of port efficiency was adopted from the work of M.J Farrell. Several failed attempts to show the relationship between increased output and its corresponding efficiency led to this concept; which combined inputs to the agricultural sector of the United States (Farrell, 1957). Existing pieces of literature gave a comprehensive insight into port efficiency (Wang et al., 2005). In measuring port efficiencies, numerous techniques have been developed over the years. Most of these measures are considered to be parametric or non-parametric; with others also supporting port efficiency calculations. These techniques include the Data Envelopment Analysis (DEA), Stochastic Frontier Analysis (SFA), Multiple Linear Regression (MLR), Total Factor Productivity (TFP), and the Free Hull Disposal (FHD). DEA and SFA are mostly used for measuring efficiencies with methodologies of (Chen et al., 2018; Cullinane et al., 2002; Cullinane \& Song, 2006; Kutin et al., 2017; Liu, 2010; Martinez-Budria, Diaz-Armas, Navarro-Ibanez, \& Ravelo-Mesa, 1999; Poitras et al., 1996; Roll \& Hayuth, 1993; Sarriera et al., 2013; Tongzon, 2001; van Dyck, 2015; Wang \& Han, 2018; Yang et al., 2011; Zahran et al., 2017) using these models to evaluate efficiency in the maritime industry.

\subsection{Port Adaptation Strategies of Ghanaian Ports: The Research Gaps}

Literature concerning the study has been reviewed in this chapter. The concept of climate change and the impact of climate change were then reviewed to give in-depth knowledge. Since this research is focused on the maritime industry, climate change in the maritime industry, port adaptation strategies, and efficiency papers were also reviewed. Unquestionably, numerous studies have been conducted in the areas of climate change and port efficiency with few concentrating on port adaptation. (van Dyck, 2015) in the quest to determine a "gateway" port for West African analysed the efficiency of some selected ports in West Africa using the window analysis of Data Envelopment Analysis. However, none of the studies reviewed have analysed port adaptation with regards to efficiency for West African ports to then narrow it down to Ghanaian ports like studies of (Mutombo \& Ölçer, 2016) which analysed the degree of climate change risk to the infrastructures at some selected ports in the world.

\section{Methodology}

This paper adopts a quantitative approach in tackling the research questions and achieving the aim of this research. To facilitate the research study, panel data from the research area is being used; the rationale in using panel data was the determination of the efficiency for Ghanaian ports. Panel data used in determining the efficiencies of ports have been used by numerous researchers (Cullinane \& Song, 2006; Estache et al., 2002; González \& Trujillo, 2007; Rodriguez-Alvarez et al., 2007; Wang et al., 2003; Wang et al., 2005). DEA model will 
be used to analyse the past and future efficiencies of the ports based on the panel data. The panel data used in calculating the past efficiencies of the ports were selected within a twelve (12) year period frame (2009-2020) while future efficiency scores will be calculated based on forecasted panel data for a twenty (20) year period (2021-2040); which will then be grouped into input and output decision-making units (DMUs) to estimate the efficiency using the DEAFrontier Software. In determining the significance of port adaptation and efficiency, the linear mixed model (LMM) and one-way ANOVA in SPSS were adopted. Questionnaires were distributed to various port users to assess the adaptation level of the various ports understudy for past years; the response was used as the annual port adaptation scores while telephone interview was done to assess the various future port adaptation strategies implemented by port authorities. In determining the adaptation scores for the future, dummy variables of 1-2 were assigned to the years with and without implemented strategies. The adaptation strategies (Figure 1) included four (4) major variables that are likely to influence port adaptation.

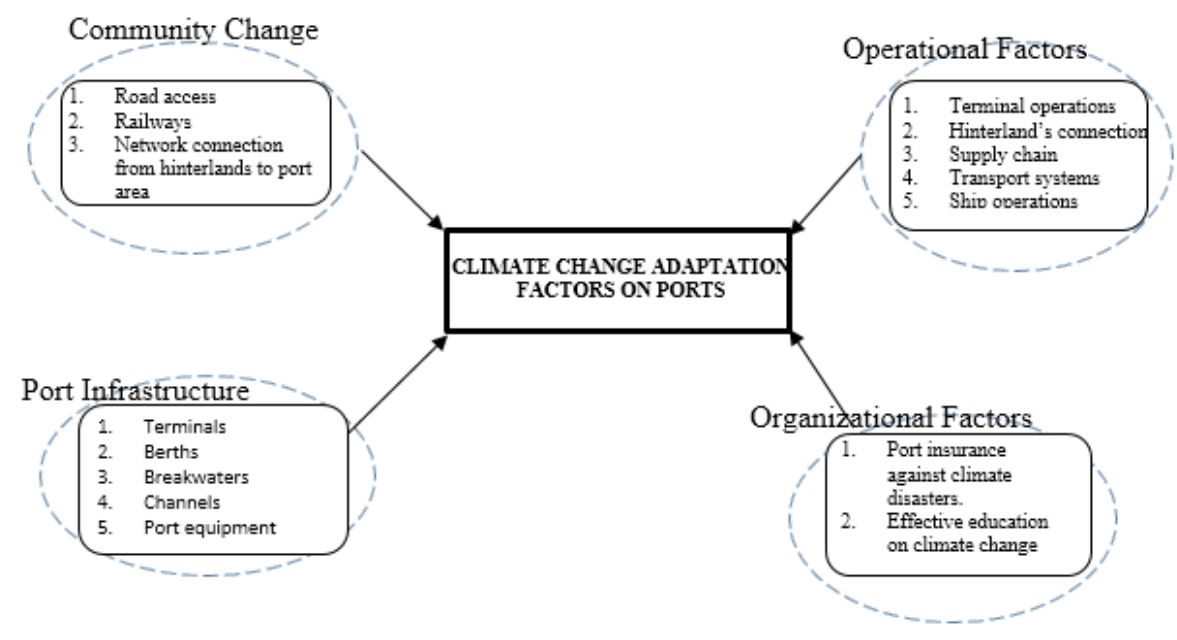

Figure1. Factors that affect port adaptation

Source: Author (2021) Based on literature from (Becker, 2020).

\subsection{Input and Output Variables}

This section focuses on the input and output DMUs to be considered in this research in other to achieve the first leg of the research; thus, past and future annual port efficiency of Ghanaian ports. Numerous researchers often use more than one (1) input variable against one (1) output variable to assess the port efficiency. This research however intends to use five (5) input DMUs against three (3) output DMUs for both ports; Tema and Takoradi ports for a twelve (12) year and twenty (20) year period. The input DMUs intended to be used for analysing the annual efficiencies for Ghanaian ports are; number of cranes, quay length, terminal area, number of berths, and number of reach stackers. The output determines how efficient the port is per the number of input variables and the variables is; total annual throughput: this is divided into annual container throughput and others; with others including 
liquid, general cargo, dry bulk, and many others and annual ship calls. The descriptive statistics of both ports are analysed in Tables 1 and 2 .

Table 1. Descriptive statistics of Tema port for 2009-2020

\begin{tabular}{lllll}
\hline Variables & Minimum & Maximum & Mean & Standard deviation \\
\hline $\begin{array}{l}\text { Cargo throughput } \\
\text { (TEUs) }\end{array}$ & $525,694.00$ & $1,286,161.00$ & $849,852.00$ & 202575.53 \\
$\begin{array}{l}\text { Ship calls } \\
\text { Other cargo }\end{array}$ & $1,464.00$ & 1,787 & & \\
traffic & $6,990,796$ & $18,086,832$ & $1,573.00$ & 91.465 \\
Number of cranes & 6.00 & & & $3,297,087.12$ \\
Number of berths & 12.00 & 27.00 & 10.83 & 7.63 \\
Number of reach & 10.00 & 22.00 & 14.08 & 3.96 \\
stackers & & 30.00 & 22.08 & 7.94 \\
Quay length (m) & 574.00 & 575.00 & & \\
Terminal area (h) & 10.00 & 10.00 & 574.17 & 0.39 \\
\hline
\end{tabular}

Table 2. Descriptive statistics of Takoradi port for 2009-2020

\begin{tabular}{|c|c|c|c|c|}
\hline Variables & Minimum & Maximum & Mean & $\begin{array}{l}\text { Standard } \\
\text { deviation }\end{array}$ \\
\hline $\begin{array}{l}\text { Cargo throughput } \\
\text { (TEUs) }\end{array}$ & $38,350.00$ & $61,355.00$ & $52,296.25$ & $6,504.23$ \\
\hline Ship calls & 956.00 & $1,886.00$ & $1,484.17$ & 276.88 \\
\hline $\begin{array}{l}\text { Other } \\
\text { traffic }\end{array}$ & $3,324,152.00$ & $10,336,616.00$ & $6,068,568.83$ & $2,135,446.14$ \\
\hline Number of cranes & 4.00 & 5.00 & 4.67 & 0.50 \\
\hline Number of berths & 9.00 & 13.00 & 10.08 & 1.78 \\
\hline $\begin{array}{l}\text { Number of reach } \\
\text { stackers }\end{array}$ & 8.00 & 11.00 & 10.25 & 1.14 \\
\hline Quay length (m) & 500.00 & 500.00 & 500.00 & 0.00 \\
\hline Terminal area (h) & 39.00 & 39.00 & 39.00 & 0.00 \\
\hline
\end{tabular}

\subsection{Efficiency of Each Port}

To proceed with the analysis of data, the annual efficiency of each port is calculated using the DEA Frontier software with the above DMUs. The total number of DMUs for this research is twelve (12), with five (5) input variables and three (3) output variables. In calculating the annual efficiencies, the past input and output DMUs (12-year period) for both ports remained constant while a forecast was made for the output variables for the 20 -year period using an 
annual growth of $10 \%$ for containers and cargo throughput. An annual growth rate of $4 \%$ was also used to forecast the number of ship calls. Only the output variables for the 20year period were forecasted since it was assumed that no further expansion will be done at the various ports till the concession agreement period for the new expansion project has been terminated or completed. DEA model performed for this research is the constant return to scale (CRS) or the CCR- DEA model with an input-oriented variable which examines if a unit uses more input to produce an output. For the twelve years (2009-2020) under review with the various inputs and outputs, Tema port attained an efficiency of 100\% (CRS of 1) with a "constant" return to scale for six (6) years and the remaining years having an increasing return to scale (IRS). Takoradi port, on the other hand, had a CRS for eight (8) years from 2009-2020. For the twenty (20) year period, Tema port is expected to have a combination of CRS and IRS, same for Takoradi port.

\subsection{Determining the Past and Future Adaptation Scores for Each Port}

The past and future adaptation scores for each port were calculated based on questionnaires and interviews respectively. The variables were collated based on plausible factors affecting climate change adaptation; organizational factors, community change, port infrastructure, and operational factors (Becker, 2020).

To determine the port adaptation scores for 2009-2020, questionnaires were distributed to various users of the ports understudy to examine the annual adaptation level of the ports based on the period for the research. The questionnaire was based on the four (4) major factors affecting adaptation and was divided into sub-variables, totalling 16 variables. Each participant was required to answer the questionnaire based on their knowledge of the port's approach to adaptation over the year of the research using the Likert scale. In total, each participant was required to answer 48 questions (without the subdivisions) based on the selected adaptation variables. The Likert scale had 1 to be "Strongly Disagree," 2 "Disagree," 3 "Undecided," 4 "Agree," and 5 as "Strongly Agree." The data was collated from different users of Ghanaian ports, their knowledge and history on climate change and its impacts, adaptation, and investments plans for the port. Port users were purposively selected which included terminal operators, operations department, and some selected logistics companies. Online questionnaires were administered through emails. Out of the initial 57 participants, 36 valid responses were submitted for Tema port and 34 for Takoradi port. The respondents comprised persons in different managerial levels at the various ports. The research aiming to assess the significance of port adaption and efficiency; however, used other variables after the questionnaire responses were assessed. The gender and education level of respondents were taking into consideration. The composite scores of the subdomain of each variable in the questionnaire were used as the annual adaptation scores for 2009-2020. In summary, port efficiency, sex, and level of education of respondents were used as the independent variables while the dependent variable was port adaptation scores. Cronbach's alpha was used to test the reliability of the questionnaire samples received (Appendix).

To determine the adaptation scores for the forecasted years (2021-2040), managers at the operations department for both ports were interviewed to explore the various adaptation 


\section{Macrothink}

International Journal of Regional Development

ISSN 2373-9851

2021, Vol. 8, No. 2

strategies (either soft or hard strategies) likely to be implemented by the port authorities, to reduce the impact of climate change for the coming years. Due to the lack of data on present and future port adaptation strategies at the various ports, the researcher had to introduce dummy variables to achieve the aim of the research. The forecasted port efficiencies were tallied with the expected adaptation scores (Table 3). Based on the interview, it was concluded much attention has not yet be given to adaptation strategies by the port authorities. The interview covered the four (4) major variables that influence port adaptation from the researcher's perspective. To achieve the aim of this research, some assumptions were made by the researcher which includes;

(1) The conditions of facilities before and after the expansion projects at each port.

(2) The facilities that were improved or added to reduce the impact of climate change at the various ports.

(3) The year the facility or equipment was brought to the port.

(4) The knowledge of port users on climate change and adaptation at the various ports.

Table 3. Forecasted port efficiency and adaptation scores for 2021-2040

\begin{tabular}{lllll}
\hline Year & Forecasted Efficiency & Adaptation Score & Forecasted Efficiency & Adaptation Score \\
\hline & Tema Port & & Takoradi Port & \\
\hline $\mathbf{2 0 2 1}$ & 0.92 & 1 & 0.69 & 2 \\
$\mathbf{2 0 2 2}$ & 0.96 & 2 & 0.71 & 1 \\
$\mathbf{2 0 2 3}$ & 1.00 & 2 & 0.74 & 1 \\
$\mathbf{2 0 2 4}$ & 0.85 & 1 & 0.77 & 1 \\
$\mathbf{2 0 2 5}$ & 0.89 & 1 & 0.80 & 1 \\
$\mathbf{2 0 2 6}$ & 0.92 & 1 & 0.83 & 1 \\
$\mathbf{2 0 2 7}$ & 0.96 & 1 & 0.87 & 1 \\
$\mathbf{2 0 2 8}$ & 1.00 & 1 & 0.90 & 1 \\
$\mathbf{2 0 2 9}$ & 1.00 & 1 & 0.84 & 1 \\
$\mathbf{2 0 3 0}$ & 1.00 & 1 & 0.68 & 1 \\
$\mathbf{2 0 3 1}$ & 0.70 & 1 & 0.70 & 1 \\
$\mathbf{2 0 3 2}$ & 0.73 & 1 & 0.73 & 1 \\
$\mathbf{2 0 3 3}$ & 0.76 & 1 & 0.76 & 1 \\
$\mathbf{2 0 3 4}$ & 0.79 & 1 & 0.79 & 1 \\
$\mathbf{2 0 3 5}$ & 0.82 & 1 & 0.82 & 1 \\
$\mathbf{2 0 3 6}$ & 0.85 & 1 & 0.85 & 1 \\
$\mathbf{2 0 3 7}$ & 0.89 & 1 & 0.89 & 1 \\
$\mathbf{2 0 3 8}$ & 0.92 & 1 & 0.92 & 1 \\
$\mathbf{2 0 3 9}$ & 0.96 & 1 & 0.96 & 1 \\
$\mathbf{2 0 4 0}$ & 1.00 & 2 & 1.00 & \\
\hline
\end{tabular}




\subsection{Results}

This subsection will be divided into two; the former will concentrate on the significance level of port adaption and efficiency on Ghanaian ports based on previous years (2009-2020) while the latter concentrates on future years (2021-2040).

The composite score for the annual adaptation scores for 2009-2020 for each participant in the questionnaire was based on the Likert scale used as the port adaptation scores. Port efficiency was treated as a repeated variable. In determining the relationship between port adaptation and efficiency, other variables were also taken into account based on the outcome of the questionnaire. A unique ID number was designated to each participant, sex is categorical; male and female. However, education is ordinal but for this study, there were two different options for education; pre-tertiary and tertiary. Port Adaptation scores were used as the dependent variable while port efficiency, sex, and education were being classified as independent variables. "Years" was treated as a random factor and a linear mixed model in SPSS (Analyze $>$ Mixed models $>$ Linear) was used to analyse the data sets. The output results from SPSS display different results depending on the command given. For this case, type III tests of fixed effects, estimates of fixed effects, and estimates of covariance parameters were computed in addition to model dimension, information, criteria, and random effect covariance structure.

In interpreting the results of the means of the data sets, only type III tests of fixed effect display the $f$ and $p$-values of the independent variables to the dependent variable and the estimates of fixed effects, given a descriptive overview of the data sets were taken into consideration. Based on the output of estimates of fixed effects, results were displayed for different efficiency scores, education, gender, and the combination of these variables. The output results are interpreted as $(\mathrm{df}))=\mathrm{t}$-statistics, $\mathrm{p}=$ significance value. Therefore, for an efficiency score of 0.90 for Tema port, its corresponding output results can be computed as; $t$ $(395.776)=.90, p=.929$ with a $95 \%$ confidence level of $[-.121163, .132741]$; the presence of negative value and less than 1 value depict the large $p$-value of the significance test. The type III tests of the fixed effects table show the collective significance level of each of the independent variables. The output results for both ports' efficiency to port adaptation can be concluded there were no significant correlations between the means of the data sets since the p-value was greater than the alpha value; significance means $.506>.05$.

This part concentrates on the significance level using one-way ANOVA in SPSS in calculating the future significance level of port adaptation and efficiency for 2021-2040. In estimating the future adaptation scores, a telephone interview was conducted for managers at the operation department of each port due to the absence of information on port adaptation strategies. Dummy variables of 1-2 were assigned to results of the interview; 1 representing years with no intended adaptation strategies (either soft or hard) and 2 for years that there will be possible implemented strategies. Based on the interview, it was concluded that less attention has been given to adaptation strategies and expansion projects were misinterpreted as adaptation strategies. 
Using one-way ANOVA (Analyze > Compare Means > One-way ANOVA) in SPSS to determine the significance level, the dummy variables representing adaptation scores were tallied against the forecasted port efficiencies for 2021-2040; with port adaptation being used as the factor variable while port efficiency being the dependent variable. Different tests were being performed in addition to the homogeneity test; Welch and Brown- Forsythe test which is a parametric test was used to examine the population variance of the means of data sets. The Welch test in some cases can replace the classic ANOVA output.

For this output, the results of the descriptive statistics and the robust tests of equality of means were interpreted. For easy analysis in SPSS, the "1" value was labelled as "unapplicable" while " 2 " was "applicable." The descriptive statistics table gave a summary of the standard deviation, standard error, and confidence intervals of the data sets. The robust tests of equality of means also gave a summary of the significance level of the means of the data sets. The means of the data sets for Tema port is reported as; FWelch $=(1,15.014)=$ 15.904, $p=0.01$ and $F_{\text {Welch }}=(1,8.425)=25.724, p=0.01$ for Takoradi port; which were the same values for the Brown-Forsythe test. Based on the results, it was therefore concluded, there was a significant correlation between port efficiency and adaptation for the two ports understudy for 2021-2040 since the p values were less than the alpha value of .05

\section{Research Findings}

This subsection will be divided into two; the former will concentrate on the significance level of port adaption and efficiency on Ghanaian ports based on previous years (2009-2020) and future years (2021-2040) while the latter will concentrate on policy implications for Ghanaian port authorities.

\subsection{Key Findings}

To achieve the aim of this research, two empirical studies were analysed; first, the significance level of port efficiency and adaptation for 2009-2020, and the second part was for 2021-2040; which was described as the forecasted or expected significance level using panel data set. Firstly, the annual efficiencies for 2009-2020 of both ports were calculated using various variables as inputs and outputs using DEA Frontier software. The annual adaptation scores were achieved through a questionnaire based on the Likert scale. In determining the significance level of the forecasted efficiencies and expected adaptation scores, the forecasted efficiencies were calculated using 2020 as a base year and an annual growth rate of $10 \%$ for container and other cargo throughput and a $4 \%$ annual growth rate for ship calls. The growth rates were based on the proposed expected growth policy by GPHA with everything being constant. The forecasted value for the output DMU variables varied since there was expected to be an increase, however, the input DMU variables remained constant because it was assumed that no expansion project will be done within the 20year period. The new efficiency scores were also determined using DEA Frontier software.

Forecasted port efficiency scores were tallied against port adaptation scores using dummy variables of 1 and 2; with ones (1) being labelled as "unapplicable" and "applicable" for twos and one-way ANOVA in SPSS being used to analyse the significance level of the tallied data 
set. The $p$-value for both ports for 2009-2020 was greater than the alpha value $(p>0.05)$ and hence, there was no significant correlation between the means of the data sets. However, the significance level for 2020-2040 was less than the alpha value (significance means $0.001<0.05$ ), therefore, it can be concluded that there is a significant correlation between the data set.

\subsection{Policy Implications for Ghanaian Port Authorities}

The vision of GPHA is to make ports in Ghana a gateway to West Africa, however, due to the results of this study, the need for port adaptation to be giving much attention in coming years is important while actualizing their vision. GPHA needs to implement new policies of port adaptation to their existing visionary policies. These policies should include:

a)

GPHA must outline their adaptation strategies for ports in Ghana including dry ports.

b)

Education and training of staff and stakeholders on climate change.

c)

Continuous resilience assessment and maintenance of port facilities.

d) In determining the impact that climate change has on port efficiency, GPHA should consider all variables and drivers of climate change that affect the two major ports in Ghana.

e) In assessing the degree of port adaptation to efficiency and performance, GPHA should also have an adaptation strategy that covers operational, environmental, infrastructure, and even the harbor areas.

a. Port authorities must consider possible investments towards port adaptation since this concept is far different from port expansion. Moreover, port authorities must be strategic about the investment plan; the best time to invest to mitigate the consequences of climate change in the future.

\section{Conclusion}

In this paper, the significant relationship between efficiencies (past and forecasted) and adaptation strategies for Ghanaian ports were determined. Panel data from 2009-2020 were used for both ports in determining the annual efficiencies using DEAFrontier software whiles the efficiencies for 2021-2040 were forecasted using an expected growth rate of $10 \%$ for the cargo and container throughput with a rate of $4 \%$ for the number of ship calls. Input DMUs remained constant for the forecasted efficiencies with variations in the output DMUs. The adaptation scores were determined using questionnaires and telephone interviews for past years and coming years respectively. The composite scores for the questionnaires were used as the adaptation scores for 2009-2020 while dummy variables of 1 and 2 were assigned as the adaptation scores for 2021-2040 based on the interview results. Using LMM in SPSS to determine the relationship between efficiency and adaption scores for 2009-2020, a p-value greater than .05 was achieved indicating there were no correlations between the data sets; however, the significant relationship for the forecasted data sets using ANOVA indicated a 
significant correlation between the data sets with a p-value less than .05 for both ports. Based on the output of the results, it can be concluded port adaptation did not have an impact on Ghana port's efficiency in the past years, however, the coming years (2021-2040) will be different and the likelihood of port adaptation affecting the port's efficiencies are high and inevitable.

\subsection{Strategic Prospect for Future Research}

A commendable climate adaptation does not only focus on the improvement of ports infrastructure but involves organizational, operational, and community change (Becker, 2020). Obtaining a $(\mathrm{p}<.05)$ for future port efficiency and adaptation based on different variables of adaptation strategies depict the fact that adaptation takes into account not only the infrastructural improvements of the ports but other invisible variables. It is, therefore, recommended that subsequent researches should use additional variables that can contribute to a positive port adaptation strategy to determine the relationship between port efficiency and adaptation. Using more adaptation variables also requires the use of a statistical tool that can analyse the efficiency and adaptation variables. In terms of the study area, an empirical study for ports in the Sub Sahara region can be considered using the same approach since a cumulative concern about the impact of climate change in this region remains a huge burden for port authorities and stakeholders. Much attention has been given to efficiency concerning expansion projects at the various ports in this region (van Dyck, 2015) with no information on climate adaptation (port adaptation) on Sub Saharan ports nor existing literature published to that effect (based on the author's best knowledge) during the data collection and literature review for the research.

\section{Acknowledgments}

We would like to thank Professor Shiyuan Zheng of the College of Transport and Communication of Shanghai Maritime University for his expert knowledge in the completion of this manuscript and staff of the Operations Department of Ghana Ports and Harbour Authority (GPHA) for their assistance and cooperation during data collection for this paper. Other thanks go to Miss Ruhaimatu Abudu (corresponding author) for her immense contribution towards the completion of this paper as well as the co-author Mr. Emmanuel Anu Thompson. The authors would also like to thank the Editors for their valuable suggestions.

\section{Disclosure statement}

No potential conflict of interest was reported by the authors.

\section{Funding}

There was no agency funding for this work.

\section{References}

Aigner, D., Lovell, C. A. K., \& Schmidt, P. (1977). Formulation And Estimation Of Stochastic Frontier Production Function Models. 
Becker, A. (2020). Climate change impacts to ports and maritime supply chains. https://doi.org/10.1080/03088839.2020.1800854

Becker, A., Acciaro, M., Asariotis, R., Cabrera, E., Cretegny, L., Crist, P., LEsteban, M., Mather, A., Messner, S., Naruse, S., Ng, A. K. Y., Rahmstorf, S., Savonis, M., Song, D. W., Stenek, V., \& Velegrakis, A. F. (2013). A note on climate change adaptation for seaports : A challenge for global ports, a challenge for global society. Springer, 120(4), 683-695.

Becker, A., Inoue, S., \& Fischer, M. (2012). Climate change impacts on international seaports: Knowledge, perceptions, and planning efforts among port administrators. https://doi.org/10.1007/s10584-011-0043-7

Brooks, N. (2003). Vulnerability, risk and adaptation: A conceptual framework.

Charnes, A., Cooper, W. W., \& Rhodes, E. (1978). Measuring the efficiency of decision making units. European Journal of Operational Research, 2(6), 429-444. https://doi.org/10.1016/0377-2217(78)90138-8

Chen, H. K., Chou, H. W., \& Hsieh, C. C. (2018). Operational and disaggregate input efficiencies of international container ports: An application of stochastic frontier analysis. International Journal of Shipping and Transport Logistics, 10(2), 113-159. https://doi.org/10.1504/IJSTL.2018.090092

Cooper, W. W., \& Seiford, L. M. (2007). DATA ENVELOPMENT ANALYSIS A Comprehensive Text with Models, Applications, References and DEA-Solver Software Second Edition.

Cullinane, K., \& Song, D. W. (2006). Estimating The Relative Efficiency Of European Container Ports: A Stochastic Frontier Analysis. https://doi.org/10.1016/S0739-8859(06)16005-9

Cullinane, K., Song, D. W., \& Gray, R. (2002). A stochastic frontier model of the efficiency of major container terminals in Asia: Assessing the influence of administrative and ownership structures. Transportation Research Part A: Policy and Practice, 36(8), 743-762. https://doi.org/10.1016/S0965-8564(01)00035-0

Cullinane, K., Song, D. W., \& Wang, T. (2005). The application of mathematical programming approaches to estimating container port production efficiency. Journal of Productivity Analysis, 24(1), 73-92. https://doi.org/10.1007/s11123-005-3041-9

Cullinane, K., \& Wang, T. (2010). The efficiency analysis of container port production using DEA panel data approaches. OR Spectrum, 32(3), 717-738. https://doi.org/10.1007/s00291-010-0202-7

Davarzani, H., Fahimnia, B., Bell, M., \& Sarkis, J. (2016). Greening ports and maritime logistics: A review. Transportation Research Part D, 48, 473-487. https://doi.org/10.1016/j.trd.2015.07.007

Duncan McIntosh, R., \& Becker, A. (2017). Seaport climate vulnerability assessment at the 
multi-port scale : a review of Approaches. Springer, 205-224.

Dyck, G. K. Van. (2015). Assessment of Port Efficiency in West Africa Using Data Envelopment Analysis (pp. 208-218).

Estache, A., González, M., \& Trujillo, L. (2002). Efficiency Gains from Port Reform and the Potential for Yardstick Competition: Lessons from Mexico.

Fahimnia, B., Jabbarzadeh, A., \& Sarkis, J. (2015). A tradeoff model for green supply chain planning:A leanness-verse-greeness analysis. Omega, February. https://doi.org/10.1016/j.omega.2015.01.014

Farrell, M. J. (1957). The Measurement of Productive Efficiency. Journal of the Royal Statistical Society. Series A (General), 120(3), 253. https://doi.org/10.2307/2343100

Førsund, F. R., Lovell, K., Schmidt, P., Fqrsund, F. R., \& Lovell, C. A. K. (1980). A Survey of Frontier Production Functions and of Their Relationship to Efficiency Measurement. https://doi.org/10.1016/0304-4076(80)90040-8

González, M. M., \& Trujillo, L. (2007). Efficiency measurement in the port industry: A survey of the empirical evidence. 08.

Gouldby, B., \& Hunter, P. (2021). Climate change and ports Impacts and adaptation strategies.

Itoh, H. (2002). Efficiency Changes At Major Container Ports In Japan: A Window Application Of Data Envelopment Analysis. In RURDS (Vol. 14, Issue 2).

Kreft, S., Eckstein, D., \& Melchior, I. (2017). Global climate risk index.

Kutin, N., Nguyen, T. T., \& Vallée, T. (2017). Relative Efficiencies of ASEAN Container Ports based on Data Envelopment Analysis. Asian Journal of Shipping and Logistics, 33(2), 67-77. https://doi.org/10.1016/j.ajsl.2017.06.004

Liu, Q. (2010). Efficiency analysis of container ports and terminals. Doctoral Thesis, UCL (University College London).

Martinez-Budria, E., Diaz-Armas, R., Navarro-Ibanez, M., \& Ravelo-Mesa, T. (1999). A study of the efficiency of Spanish port authorities using data envelopment analysis. International Journal of Transport Economics/Rivista Internazionale Di Economia Dei Trasporti, 237-253.

Messner, S., Becker, A., \& Ng, A. K. Y. (2016). Seaport adaptation for climate change - The roles of stakeholders and the planning process. Retrieved from https://www.researchgate.net/publication/301627594_Seaport_adaptation_for_climate_chang e_-_The_roles_of_stakeholders_and_the_planning_process

Mutombo, K., \& Ölçer, A. (2016). Towards port infrastructure adaptation: a global port climate risk analysis. https://doi.org/10.1007/s13437-016-0113-9 


\section{Macrothink}

International Journal of Regional Development

ISSN 2373-9851

2021, Vol. 8, No. 2

Mutombo, K., \& Ölçer, A. (2017). Towards port infrastructure adaptation : A global port climate risk analysis. Springer, 161-173. https://doi.org/10.1007/s13437-016-0113-9

Ng, A. K. Y., Chen, S., Cahoon, S., Brooks, B., \& Yang, Z. (2013). Climate change and the adaptation strategies of ports: The Australian experiences. RTBM, 8, 186-194. https://doi.org/10.1016/j.rtbm.2013.05.005

Notteboom, T. E., \& Rodrigue, J. (2007). Port regionalization : towards a new phase in port development. 8839. https://doi.org/10.1080/03088830500139885

Poitras, G., Tongzon, J., \& Li, H. (1996). Measuring Port Efficiency: An Application of Data Envelopment Analysis, 4(3), 57-71. http://marefateadyan.nashriyat.ir/node/150

Randrianarisoa, L. M., \& Zhang, A. (2019). Adaptation to climate change effects and competition between ports: Invest now or later? Transportation Research Part B, 123, 279-322. https://doi.org/10.1016/j.trb.2019.03.016

Rodriguez-Alvarez, A., Tovar, B., \& Trujillo, L. (2007). Firm and time varying technical and allocative efficiency: An application to port cargo handling firms. Int. J. Production Economics, 109, 149-161. https://doi.org/10.1016/j.ijpe.2006.12.048

Roll, Y., \& Hayuth, Y. (1993). Port performance comparison applying data envelopment analysis (DEA). Maritime Policy and Management, 20(2), 153-161. https://doi.org/10.1080/03088839300000025

Sarriera, J. M., Araya, G., Serebrisky, T., Briceño-Garmendía, C., \& Schwartz, J. (2013). Benchmarking Container Port Technical Efficiency in Latin America and the Caribbean: A Stochastic Frontier Analysis. The World Bank. https://doi.org/10.1596/1813-9450-6680

Schmidt, P., \& Sickles, R. C. (2015). Production Frontier and Panel Data. https://doi.org/10.2307/1391278

Slack, B., \& Comtois, C. (2016). Climate change and adaptation strategies of Canadian ports and shipping: The case of the St. Lawrence-Great Lakes system.

Song, D., \& Parola, F. (2015). Strategising port logistics management and operations for value creation in global supply 5567. https://doi.org/10.1080/13675567.2015.1031094

Stopford, M. (2009). Maritime Economics.

Tongzon, J. (2001). Efficiency measurement of selected Australian and other international ports using data envelopment analysis. www.elsevier.com/locate/tra

van Dyck, G. K. (2015). The Drive for a Regional Hub Port for West Africa: General Requirements and Capacity Forecast. 36-44. https://doi.org/10.11648/j.ijber.20150402.13

Wang, T-F ; Song, D.-W. ; \& Cullinane, K. (2003). Container Port Production Efficiency: A Comparative Study of DEA and FDH Approaches. 


\section{Macrothink}

International Journal of Regional Development

ISSN 2373-9851

2021, Vol. 8, No. 2

Wang, Teng-Fei, Cullinane, K., \& Song, D.-W. (2005). Container Port Production and Economic Efficiency.

Wang, Y.-J., \& Han, T.-C. (2018). Efficiency Measurement For International Container Ports Of Taiwan And Surrounding Areas By Fuzzy Data Envelopment Analysis. Journal of Marine Science and Technology, 26(2), 185-193. https://doi.org/10.6119/JMST.2018.04_(2).0006

World Maritime University. (2017). Shipping Operations Management. In I. D. Visvikis \& P. M. Panayides (Eds.). Springer.

Yang, H., Lin, K., Kennedy, O. R., \& Ruth, B. (2011). Sea-Port Operational Efficiency: An Evaluation of Five Asian Ports Using Stochastic Frontier Production Function Model. Journal of Service Science and Management, 4(3), 391-399. https://doi.org/10.4236/jssm.2011.43045

Yang, Y. C., \& Ge, Y. E. (2020). Adaptation strategies for port infrastructure and facilities under climate change at the Kaohsiung port. Transport Policy, 97, 232-244. https://doi.org/10.1016/j.tranpol.2020.06.019

Zahran, S. Z., Alam, J. Bin, Al-Zahrani, A. H., Smirlis, Y., Papadimitriou, S., \& Tsioumas, V. (2017). Analysis of port authority efficiency using data envelopment analysis oa. Maritime Economics and Logistics, 19(3), 518-537. https://doi.org/10.1057/mel.2015.33

\section{Appendix A}

Appendix I. Reliability (Cronbach alpha) alpha values for each subdomain

\begin{tabular}{llll}
\hline Adaptation Variable & $\begin{array}{l}\text { Variable } \\
\text { Number }\end{array}$ & Tema Port & Takoradi Port \\
\hline Port infrastructure & PI & 0.713 & 0.662 \\
Community change & CC & 0.717 & 0.557 \\
Organizational factor & OF & 0.718 & 0.747 \\
Port operations & OP & 0.700 & 0.587 \\
\hline
\end{tabular}

\section{Copyright Disclaimer}

Copyright for this article is retained by the author(s), with first publication rights granted to the journal.

This is an open-access article distributed under the terms and conditions of the Creative Commons Attribution license (http://creativecommons.org/licenses/by/4.0/). 